AperTO - Archivio Istituzionale Open Access dell'Università di Torino

Evidence of genotoxicity in lymphocytes of non-smoking alcoholics

This is a pre print version of the following article:

Original Citation:

Availability:

This version is available http://hdl.handle.net/2318/1506171

since 2017-06-27T14:19:40Z

Published version:

DOI:10.1007/s11033-014-3739-8

Terms of use:

Open Access

Anyone can freely access the full text of works made available as "Open Access". Works made available under a Creative Commons license can be used according to the terms and conditions of said license. Use of all other works requires consent of the right holder (author or publisher) if not exempted from copyright protection by the applicable law. 


\title{
3 Evidence of genotoxicity in lymphocytes of non-smoking alcoholics
}

\author{
4 Alfredo Santovito $\cdot$ Piero Cervella . \\ 5 Massimiliano Delpero
}

6 Received: 1 March 2013/Accepted: 11 September 2014

7 C) Springer Science+Business Media Dordrecht 2014

8

9
Abstract Alcohol abuse is a significant public health issue. Epidemiological studies conducted on different populations consistently showed that consumption of alcoholic beverages is associated with cytogenetic damages and higher risk for several types of cancer. However, the interpretation of many cytogenetic studies resulted complicated because some confounding factors, such as smoking habit, are not always taken into account. In the present study, the frequency of sister chromatid exchanges (SCEs), chromosome aberrations (CAs) and micronuclei (MNs) in cultured human lymphocytes was assessed on 15 alcoholic and 15 non-alcoholic control male subjects. Moreover, considering the implication of the Glutathione S-transferases gene polymorphisms in the genetic susceptibility to alcoholic liver diseases, we considered an important issue to evaluate the relationship between these gene polymorphisms and the cytogenetic damage. In our sample we exclusively considered individuals that did not smoke nor consume drugs for a period of at least 2 years prior to the analysis. Statistically significant differences were found between alcoholics and controls in the frequency of SCEs/cell $(P=0.001)$, RI value $(P=0.001)$, CAs $(P=0.002)$ and $\mathrm{CAB}(P=0.002)$. Vice versa, no significant differences were found between alcoholics and controls in terms of MNs frequency and CBPI value. In both samples, no statistically significant association was found between the analysed GSTs gene polymorphisms and the frequencies of MNs, SCEs and CAs. Finally, among alcoholics we found a positive correlation between

A. Santovito $(\varangle) \cdot$ P. Cervella $\cdot$ M. Delpero

Department of Life Sciences and Systems Biology, University of

Turin, Via Accademia Albertina n. 13, 10123 Turin, Italy

e-mail: alfredo.santovito@unito.it
SCEs and CAs frequencies and the duration of alcohol abuse.

Keywords Micronuclei - Sister chromatid exchanges . Chromosomal aberrations $\cdot$ Genotoxicity $\cdot$ Alcohol

\section{Introduction}

Alcohol abuse is a significant social and public health concern. In 1988, the International Agency for Research on Cancer (IARC) classified alcoholic drinks as group I carcinogens in humans for the upper airways, digestive tract and liver [20]. Excessive chronic ingestion of ethanol was also associated with serious damages to most of the major organ systems such as the liver, pancreas, thyroid, pituitary glands, and adrenal gland [1, 8, 21, 32, 33]. From a cytogenetic point of view, ethanol was shown to induce sister chromatid exchanges (SCEs), micronuclei (MNs), and aneuploidy in mouse eggs [38]; mis-segregation and/or nondisjunction in Aspergillus nidulans [9, 23], Drosophila melanogaster [41], and rodents [25-28], as well as MNs in Zea and Tradescantia [38].

In vivo cytogenetic studies among humans showed increased frequencies of chromosomal aberrations (CAs) [17, 38], SCEs [38], and MNs [19, 32] in peripheral blood lymphocytes of alcoholics. Nevertheless, the interpretation of some cytogenetic studies could be problematic because some confounding factors, such as smoking, were not always taken into account. It is known that alcohol dependent is usually associated with smoking habit. This association could result in further increased levels of CAs and MNs [37, 48] and cancer incidence [22, 30, 50].

In this study, we analysed the MNs, SCEs and CAs frequencies in cultured lymphocytes from a sample of nonsmoker alcoholic and non-alcoholic control subjects. MN

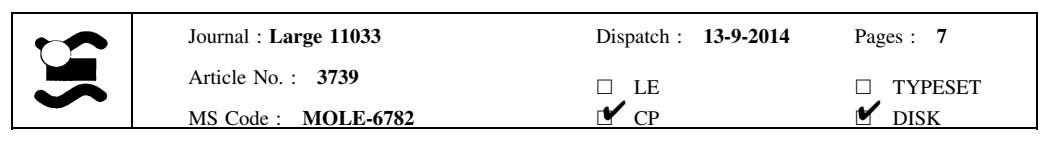




\section{Materials and methods}

\section{Groups studied}

116 The study was conducted on 15 alcoholics and 15 non-drinker 117

assay detects both clastogenicity (chromosome breakage) and aneugenicity (chromosome lagging due to dysfunction of mitotic apparatus) [12, 14, 39], while the SCE analysis reveals alterations in the chromosome structure only. Moreover, increased levels of CAs, in particular of chromosome breaks, were found closely related to cancer development [18].

Metabolism of alcohol results in the generation of several classes of DNA-adducts and/or DNA-damaging molecules, including reactive oxygen species (ROS), lipid peroxidation products and acetaldehyde [32]. These compounds were found to affect the DNA-repair systems and can contribute to the hepatocarcinogenesis process [47]. Detoxification cellular systems protect the cells from DNA damage caused by various reactive substances. Glutathione S-transferases (GSTs) represent one of the major groups of phase II detoxifying enzymes, found in virtually all eukaryotes and evolved providing protection against reactive oxygen metabolites and toxic substances present in the food and the environment [36]. In particular, the GST enzymes are able to detoxify harmful ethanol metabolites in the liver by conjugating acetaldehyde and ROS to reduced glutathione [31]. GSTT1 and GSTM1 genes are known to be polymorphic in humans for a deletion of a segment of DNA, that results in the absence of protein synthesis and consequent reduced detoxification of xenobiotics in homozygous individuals [42].

These genes have been also considered as potential candidates for alcoholic liver disease (ALD) susceptibility [34]. Savolainene et al. [46], found a statistically significant association between the occurrence of alcoholic liver cirrhosis and GSTM1 "null" genotype, suggesting that persons with homozygous deletion of the GSTMI gene could be genetically more prone to develop alcoholic liver fibrosis. Nevertheless, no data were found in literature about the possible association of GSTs gene polymorphism and cytogenetic damage in samples of alcoholics.

In this study we aimed to perform a cytogenetic analysis on lymphocytes from a selected sample of alcoholic beverage dependent individuals, in order to evaluate possible risks of genomic damage due alcohol genotoxicity. Moreover, considering the implication of the GSTs gene polymorphisms in the genetic susceptibility to alcoholic liver diseases and cancer, we considered an important issue to evaluate the possible relationship between these gene polymorphisms and the cytogenetic damage in chronic alcoholics.

controls, all males. Alcoholic subjects declared to drink
Table 1 Demographic characteristics and alcohol consumption habits of the studied groups

\begin{tabular}{lll}
\hline Characteristics & Alcoholics & Controls \\
\hline $\begin{array}{l}\text { Subjects }(n) \\
\text { Age }\end{array}$ & 15 & 15 \\
$\quad$ Mean years (SD) & $50.73(8.89)^{\mathrm{a}}$ & $\begin{array}{c}49.33 \\
(10.83)^{\mathrm{a}}\end{array}$ \\
$\begin{array}{l}\text { Range (years) } \\
\text { Alcohol habit }\end{array}$ & $36-70$ & $38-70$ \\
$\quad \begin{array}{l}\text { Years (SD) } \\
\text { Range (years) }\end{array}$ & $7.67(2.74)$ & - \\
$\begin{array}{l}\text { Daily assumption } \\
\text { Mean litres of alcoholic beverages }\end{array}$ & $3.13(2.20)$ & - \\
$\quad$ (SD) & $4-12$ & - \\
$\quad \begin{array}{l}\text { Mean grams of ethanol (SD) } \\
\quad 284.50\end{array}$ & - \\
& $(196.50)$ & \\
\hline
\end{tabular}

$S D$ Standard deviation

${ }^{\text {a }} P=0.944$

regularly both wine and distilled beverages, also during the period while the study was conducted. All participants were extensively interviewed by a specialized physician with a detailed questionnaire in order to collect meaningful information for the study. Age, smoking habits, work-related exposure to hazardous agents, dietary habits, use of therapeutic drugs and alcohol consumption were all recorded.

All subjects were selected avoiding individuals occupationally exposure to known or suspected mutagens/genotoxic agents. In our sample we exclusively considered individuals that have not consumed drugs and have not been subjected to invasive diagnostic examinations for a period of at least 2 years prior to the analysis. Among controls, 9 subjects declared to be teetotalers, and 6 occasional drinkers who declared to drink no more than one glass of wine during week-end.

All the subjects were volunteers, received information about the study and gave their written informed consent. The procedures followed in this work were in accordance with the ethical standards of the local responsible committee on human experimentation and with the Helsinki Declaration of 1975, as revised in 1983.

Blood sample collection

Blood samples were obtained by venipuncture $(5-10 \mathrm{~mL})$ and collected into heparinised tubes, for genotoxicity testing. All blood samples were coded, cooled $\left(4{ }^{\circ} \mathrm{C}\right)$, and processed within $2 \mathrm{~h}$ after collection.

Cytokinesis-block micronucleus assay

MNs assay was conducted following the protocol described in [43]. Micronuclei were scored in 1,000 bi-nucleated

\begin{tabular}{|c|c|c|c|}
\hline Journal : Large 11033 & Dispatch & $13-9-2014$ & Pages: 7 \\
\hline $\begin{array}{l}\text { Article No. : } \mathbf{3 7 3 9} \\
\text { MS Code : } \quad \text { MOLE-6782 }\end{array}$ & $\begin{array}{l}{ }^{\mathrm{LE}} \\
\boldsymbol{V}_{\mathrm{CP}}\end{array}$ & & $\begin{array}{l}\square \text { TYPESET } \\
\boldsymbol{\sim} \text { DISK }\end{array}$ \\
\hline
\end{tabular}


lymphocytes per subject, following the established criteria for the MN evaluation [15]. The cytokinesis-block proliferation index (CBPI) was calculated according to the formula: $\left[1 \times N_{1}\right]+\left[2 \times N_{2}\right]+\left[3 \times\left(N_{3}+N_{4}\right)\right] / N$, where $N_{1}-N_{4}$ represent the number of cells with 1-4 nuclei, respectively, and $N$ is the total number of cells scored.

\section{Sister chromatid exchanges assay}

SCEs assay was performed according to [45]. In order to determine the number of SCE/cell for each subject, we scored 50 well-spread second-division metaphases containing $46( \pm 1)$ chromosomes. A total of 100 cells from each donor were scored for the determination of the replication index (RI), calculated according to the formula: $R I=\left(M_{1}+2 M_{2}+3 M_{3}\right) / N$, where $M_{1}, M_{2}$ and $M_{3}$ represent the number of cells undergoing first, second, and third mitosis and $N$ is the total number of metaphase scored.

\section{Chromosomal aberrations assay}

CAs assay was performed according to [44]. For each subject, a total of 200 well-spread first-division complete metaphases were analyzed for the following categories of CAs: chromatid breaks (B'), chromosome breaks (B"), dicentrics (Dic), acentric fragments $(\mathrm{AF})$, and tri- or tetra- radials (RAD). Cells containing any type of chromosomal aberrations were scored as "cells with aberrations" (CAB).

DNA Extraction and Genotyping

Genomic DNA was extracted using the Chelex solution protocol [51]. GSTM1 and GSTT1 genotypes were determined by polymerase chain reaction (PCR) using primers described in [53] and [40], respectively. In addition, as internal control, a fragment of the $\beta$-globin gene was coamplified using the primers $5^{\prime}$-CAACTCATCCACGTTCACC- $3^{\prime}$ and $5^{\prime}$-ACACAACT-GTGTTCACTAGC-3'. PCR reactions were carried out following the procedure described in [44]. Genotypes with homozygous deletion of the GST genes are identified as "GST-null", whereas genotypes having at least one copy of the gene are "GST-positive".

Statistical analysis

Statistical analysis was assessed using the SYSTAT software statistical package (version 10.0, Inc., Chicago, Illinois, USA). The non-parametric Wilcoxon test was used to compare the mean frequencies of SCEs, MNs and CAs between alcoholics and controls. Multiple regression analysis was used to evaluate the influence of age and years of employment on SCEs, CAs and MNs frequencies of both groups. All $P$ values were two tailed and the level of statistical significance was set at $P<0.05$ for all tests.
170

Table 2 Frequency of SCEs and RI values in metaphases of lymphocytes from alcoholics and controls

\begin{tabular}{|c|c|c|c|c|c|c|c|c|}
\hline Groups & $\mathrm{N}$ & NSM & SCEs & SCEs/NSM (SE) & $\mathrm{M}_{1}$ & $\mathrm{M}_{2}$ & $\mathrm{M}_{3}$ & RI (SE) \\
\hline Alcoholics & 15 & 750 & 6,831 & $9.11(0.33)^{\mathrm{a}}$ & 559 & 353 & 288 & $1.75(0.04)^{b}$ \\
\hline GSTT1-positive & 10 & 500 & 4,581 & $9.16(0.38)^{\mathrm{c}}$ & 419 & 269 & 212 & $1.77(0.04)^{\mathrm{f}}$ \\
\hline GSTT1-null & 5 & 250 & 2,250 & $9.00(0.71)^{\mathrm{c}}$ & 140 & 84 & 76 & $1.71(0.06)^{\mathrm{f}}$ \\
\hline GSTM1-positive & 10 & 500 & 4,528 & $9.06(0.48)^{\mathrm{d}}$ & 416 & 278 & 206 & $1.76(0.05)^{\mathrm{g}}$ \\
\hline GSTM1-null & 5 & 250 & 2,303 & $9.21(0.36)^{\mathrm{d}}$ & 143 & 75 & 82 & $1.72(0.05)^{\mathrm{g}}$ \\
\hline GSTs double positives & 8 & 400 & 3,709 & $9.27(0.47)^{\mathrm{e}}$ & 374 & 245 & 181 & $1.76(0.05)^{\mathrm{h}}$ \\
\hline GSTs double nulls & 3 & 150 & 1,431 & $9.54(0.51)^{\mathrm{e}}$ & 159 & 81 & 60 & $1.67(0.07)^{\mathrm{h}}$ \\
\hline Controls & 15 & 750 & 4,019 & $5.36(0.30)^{\mathrm{a}}$ & 398 & 486 & 316 & $1.93(0.02)^{b}$ \\
\hline GSTT1-positive & 9 & 450 & 2,523 & $5.61(0.33)^{\mathrm{i}}$ & 249 & 278 & 173 & $1.91(0.02)^{\mathrm{n}}$ \\
\hline GSTT1-null & 6 & 300 & 1,496 & $4.99(0.56)^{\mathrm{i}}$ & 149 & 208 & 143 & $1.96(0.04)^{\mathrm{n}}$ \\
\hline GSTM1-positive & 8 & 400 & 2,118 & $5.30(0.44)^{*}$ & 207 & 242 & 151 & $1.91(0.03)^{\mathrm{o}}$ \\
\hline GSTM1-null & 7 & 350 & 1,901 & $5.43(0.42)^{*}$ & 191 & 244 & 165 & $1.96(0.04)^{\mathrm{o}}$ \\
\hline GSTs double positives & 7 & 3590 & 1,941 & $5.55(0.42)^{\mathrm{m}}$ & 247 & 280 & 173 & $1.89(0.03)^{\mathrm{p}}$ \\
\hline GSTs double nulls & 5 & 250 & 1,319 & $5.28(0.49)^{\mathrm{m}}$ & 154 & 201 & 145 & $1.98(0.05)^{\mathrm{p}}$ \\
\hline
\end{tabular}

Superscript letters indicate each comparison (a-p) performed between groups. In bold are highlighted the statistically significant differences (a and $b$ )

$S E$ Standard error; NSM Number of scored metaphases; SCEs Sister chromatid exchanges; $R I$ Replication index $=\left(M_{1}+2 M_{2}+3 M_{3}\right) / N$, where $M_{1}, M_{2}$ and $M_{3}$ represent the number of cells undergoing first second and third mitosis and $N$ is the total number of metaphase scored

${ }^{\mathrm{a}, \mathrm{b}} P=0.001 ;{ }^{\mathrm{c}} P=0.500 ;{ }^{\mathrm{d}} P=0.686 ;{ }^{\mathrm{e}, \mathrm{h}} P=1 ;{ }^{\mathrm{f}} P=0.500 ;{ }^{\mathrm{g}} P=0.892 ;{ }^{\mathrm{i}} P=0.753 ;{ }^{\mathrm{m}} P=0.893 ;{ }^{\mathrm{n}} P=0.143 ;{ }^{\mathrm{o}} P=0.345 ;{ }^{\mathrm{p}} P=0.068$ $* P=0.612$

\begin{tabular}{|l|lll|}
\hline Journal : Large $\mathbf{1 1 0 3 3}$ & Dispatch : 13-9-2014 & Pages : $\mathbf{7}$ \\
& Article No. : $\mathbf{3 7 3 9}$ & $\square$ LE & $\square$ TYPESET \\
& MS Code : MOLE-6782 & $\square_{\mathrm{CP}}$ & $\checkmark$ DISK \\
\hline
\end{tabular}


Table 3 Frequency of chromosomal aberrations in metaphases of lymphocytes from alcoholics and controls

\begin{tabular}{|c|c|c|c|c|c|c|c|c|c|c|c|}
\hline \multirow[t]{2}{*}{ Groups } & \multirow[t]{2}{*}{$\mathrm{N}$} & \multirow[t]{2}{*}{ NSM } & \multicolumn{7}{|c|}{ CAs } & \multirow{2}{*}{$\begin{array}{l}\text { CAs/NSM \% } \\
\text { Mean (SE) }\end{array}$} & \multirow{2}{*}{$\begin{array}{l}\text { CAB/NSM \% } \\
\text { Mean (SE) }\end{array}$} \\
\hline & & & $\mathrm{B}^{\prime}$ & B” & Dic & $\mathrm{AF}$ & RAD & Totals CAs & Totals CAB & & \\
\hline Alcoholics & 15 & 3,000 & 17 & 8 & 1 & 2 & 1 & 29 & 29 & $0.97(0.11)^{\mathrm{a}}$ & $0.97(0.11)^{b}$ \\
\hline GSTT1-positive & 10 & 2,000 & 12 & 4 & 1 & 1 & 1 & 19 & 19 & $0.95(0.11)^{\mathrm{c}}$ & $0.95(0.11)^{\mathrm{f}}$ \\
\hline GSTT1-null & 5 & 1,000 & 5 & 4 & 0 & 1 & 0 & 10 & 10 & $1.00(0.13)^{\mathrm{c}}$ & $1.00(0.13)^{\mathrm{f}}$ \\
\hline GSTM1-positive & 10 & 2,000 & 13 & 3 & 1 & 0 & 1 & 18 & 18 & $0.90(0.12)^{\mathrm{d}}$ & $0.90(0.12)^{\mathrm{g}}$ \\
\hline GSTM1-null & 5 & 1,000 & 4 & 5 & 0 & 2 & 0 & 11 & 11 & $1.10(0.11)^{\mathrm{d}}$ & $1.10(0.11)^{\mathrm{g}}$ \\
\hline GSTs double positives & 8 & 1,600 & 10 & 2 & 1 & 0 & 1 & 14 & 14 & $0.88(0.16)^{\mathrm{e}}$ & $0.88(0.16)^{\mathrm{h}}$ \\
\hline GSTs double nulls & 3 & 600 & 2 & 3 & 0 & 1 & 0 & 6 & 6 & $1.00(0.29)^{\mathrm{e}}$ & $1.00(0.29)^{\mathrm{h}}$ \\
\hline Controls & 15 & 3,000 & 0 & 1 & 0 & 2 & 1 & 4 & 4 & $0.13(0.08)^{a}$ & $0.13(0.08)^{b}$ \\
\hline GSTT1-positive & 9 & 1,800 & 0 & 1 & 0 & 1 & 1 & 3 & 3 & $0.17(0.09)^{\mathrm{i}}$ & $0.17(0.09)^{\mathrm{n}}$ \\
\hline GSTT1-null & 6 & 1,200 & 0 & 0 & 0 & 1 & 0 & 1 & 1 & $0.08(0.05)^{\mathrm{i}}$ & $0.08(0.05)^{\mathrm{n}}$ \\
\hline GSTM1-positive & 8 & 1,600 & 0 & 1 & 0 & 1 & 1 & 3 & 3 & $0.19(0.10)^{*}$ & $0.19(0.10)^{\mathrm{o}}$ \\
\hline GSTM1-null & 7 & 1,400 & 0 & 0 & 0 & 1 & 0 & 1 & 1 & $0.07(0.05)^{*}$ & $0.07(0.05)^{\mathrm{o}}$ \\
\hline GSTs double positives & 7 & 1,400 & 0 & 1 & 0 & 1 & 1 & 3 & 2 & $0.21(0.15)^{\mathrm{m}}$ & $0.14(0.09)^{\mathrm{p}}$ \\
\hline GSTs double nulls & 5 & 1,000 & 0 & 0 & 0 & 1 & 0 & 1 & 1 & $0.10(0.10)^{\mathrm{m}}$ & $0.10(0.10)^{\mathrm{p}}$ \\
\hline
\end{tabular}

Superscript letters indicate each comparison (a-p) performed between groups. In bold are highlighted the statistically significant differences (a and $b$ )

a,b $P=0.002 ;{ }^{\mathrm{c}} P=1 ;{ }^{\mathrm{d}, \mathrm{g}} P=0.257 ;{ }^{\mathrm{e}, \mathrm{h}} P=0.157 ;{ }^{\mathrm{f}} P=1 ;{ }^{\mathrm{i}} P=0.317 ;{ }^{*} \mathrm{o} P=0.414,{ }^{\mathrm{m}, \mathrm{n}, \mathrm{p}} P=0.317$

$N$ Number of tested individuals; NSM Number of scored metaphases; CAs Chromosome aberrations, B' Chromatid breaks; $B$ " Chromosome breaks; Dic Dicentric chromosome; $A F$ Acenatric fragments, $R A D$ Tri- or tetra-radials; $C A B$ Cells with aberrations; $A B . C \%$ percentage of cells with aberrations

\section{Results}

Table 1 summarizes the main characteristics of the two studied groups. Alcoholic subjects had a mean age of $50.73 \pm$ 8.89 years (range: $36-70$ years) and an average duration of alcohol abuse of $7.67 \pm 2.74$ years (range: $4-12$ years). The mean age of controls was $49.33 \pm 10.83$ years (range: $38-70$ ). No significant differences were found between groups in terms of mean age $(P=0.944)$.

Table 2 reports the SCEs frequencies recorded in peripheral blood lymphocytes of alcoholics and control subjects. A total of 750 metaphases for each group were analysed. Statistically significant differences were found between alcoholics and controls in both SCEs/cell frequency $(P=0.001)$ and RI value $(P=0.001)$.

Table 3 shows the CAs frequencies in the two subject groups. A total of 3000 metaphases for each group were analysed. Statistically significant differences were found between alcoholics and controls in terms of $\mathrm{CAs}$ and $\mathrm{CAB}$ frequencies $(P=0.002)$.

Table 4 shows the frequencies of MNs and cells with MNs in the studied groups. A total of 15,000 bi-nucleated cells for each group were scored. No statistical significant differences were found between alcoholics and controls in the frequency of MNs $(P=0.509)$, cells with MNs $(P=0.394)$ and CBPI values $(P=0.691)$.
Among both the alcoholics and control groups, we did not find statistically significant associations between any GST genes polymorphisms and the frequencies of SCEs (Table 2), CAs (Table 3) or MNs (Table 4).

Results of multiple regression analysis are summarized in Table 5. The duration of alcohol exposure (expressed as years of alcohol abuse) was seen to have effects on the frequencies of SCEs $(P=0.015)$, CAs $(P=0.45)$, but not on MNs frequency $(P=0.396)$. Finally, in both groups, no significant correlations were found between the age of subjects and the frequencies of the analysed cytogenetic biomarkers.

\section{Discussion}

Epidemiological studies conducted on different human populations consistently showed that consumption of alcoholic beverages is associated with a higher risk for several types of cancer, such as oral, pharyngeal, colorectal and liver cancers [21]. Nevertheless, the interpretation of some cytogenetic studies is complicated by factors, such as smoking or other potential confounders, not always taken into account. Specifically, the effects of smoking and alcohol consumption appear to be multiplicative. It seems plausible that the synergism between tobacco and alcohol

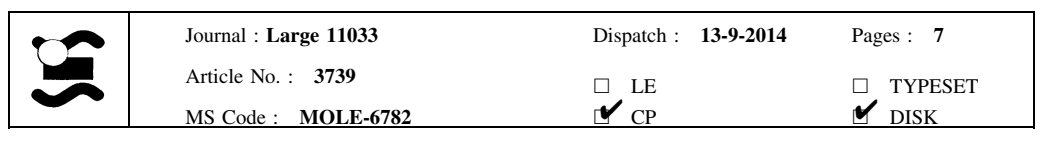


Table 4 Frequencies of MNs, Cells with MNs and CBPI values in bi-nucleated lymphocytes from alcoholics and controls

\begin{tabular}{|c|c|c|c|c|c|c|c|c|c|c|c|}
\hline \multirow[t]{2}{*}{ Groups } & \multirow[t]{2}{*}{$\mathrm{N}$} & \multirow[t]{2}{*}{ NSCs } & \multicolumn{6}{|c|}{$\begin{array}{l}\text { Distribution of BNCs according to the } \\
\text { number of MNs }\end{array}$} & \multirow[t]{2}{*}{$\%$ MNs/NSCs (SE) } & \multirow[t]{2}{*}{ \% CMNs/NSCs (SE) } & \multirow[t]{2}{*}{ CBPI (SE) } \\
\hline & & & 1 & 2 & 3 & 4 & Total MNs & $\begin{array}{l}\text { Total } \\
\text { CMNs }\end{array}$ & & & \\
\hline Alcoholics & 15 & 15,000 & 163 & 26 & 11 & 0 & 248 & 205 & $1.65(0.23)^{\mathrm{a}}$ & $1.37(0.20)^{\mathrm{b}}$ & $1.91(0.06)^{\mathrm{c}}$ \\
\hline GSTT1-positive & 10 & 10,000 & 111 & 20 & 6 & 0 & 169 & 142 & $1.69(0.23)^{\mathrm{d}}$ & $1.42(0.16)^{\mathrm{g}}$ & $1.97(0.05)^{1}$ \\
\hline GSTT1-null & 5 & 5,000 & 52 & 6 & 5 & 0 & 79 & 163 & $1.58(0.58)^{\mathrm{d}}$ & $1.26(0.54)^{\mathrm{g}}$ & $1.78(0.14)^{1}$ \\
\hline GSTM1-positive & 10 & 10,000 & 93 & 17 & 5 & 0 & 142 & 120 & $1.42(0.24)^{\mathrm{e}}$ & $1.20(0.19)^{\mathrm{h}}$ & $1.97(0.07)^{\mathrm{m}}$ \\
\hline GSTM1-null & 5 & 5,000 & 70 & 9 & 6 & 0 & 106 & 85 & $2.12(0.48)^{\mathrm{e}}$ & $1.70(0.44)^{\mathrm{h}}$ & $1.80(0.25)^{\mathrm{m}}$ \\
\hline GSTs double positives & 8 & 8,000 & 85 & 16 & 4 & 0 & 129 & 110 & $1.61(0.25)^{\mathrm{f}}$ & $1.38(0.19)^{\mathrm{i}}$ & $1.99(0.07)^{\mathrm{n}}$ \\
\hline GSTs double nulls & 3 & 3,000 & 44 & 5 & 4 & 0 & 66 & 53 & $2.20(0.78)^{\mathrm{f}}$ & $1.77(0.44)^{\mathrm{i}}$ & $1.73(0.19)^{\mathrm{n}}$ \\
\hline Controls & 15 & 3,000 & 146 & 10 & 14 & 0 & 208 & 170 & $1.39(0.28)^{\mathrm{a}}$ & $1.13(0.21)^{\mathrm{b}}$ & $1.95(0.07)^{\mathrm{c}}$ \\
\hline GSTT1-positive & 9 & 9,000 & 99 & 8 & 12 & 0 & 151 & 119 & $1.68(0.43)^{\mathrm{o}}$ & $1.32(0.32)^{\mathrm{r}}$ & $1.96(0.10)^{\mathrm{u}}$ \\
\hline GSTT1-null & 6 & 6,000 & 47 & 2 & 2 & 0 & 57 & 51 & $0.95(0.23)^{\mathrm{o}}$ & $0.85(0.18)^{\mathrm{r}}$ & $1.94(0.08)^{\mathrm{u}}$ \\
\hline GSTM1-positive & 8 & 8,000 & 75 & 8 & 7 & 0 & 112 & 90 & $1.40(0.43)^{\mathrm{p}}$ & $1.13(0.31)^{\mathrm{s}}$ & $1.85(0.08)^{\mathrm{v}}$ \\
\hline GSTM1-null & 7 & 7,000 & 71 & 2 & 7 & 0 & 96 & 80 & $1.37(0.40)^{\mathrm{p}}$ & $1.14(0.31)^{\mathrm{s}}$ & $2.07(0.10)^{\mathrm{v}}$ \\
\hline GSTs double positives & 7 & 7,000 & 66 & 7 & 7 & 0 & 101 & 80 & $1.44(0.49)^{\mathrm{q}}$ & $1.14(0.36)^{\mathrm{t}}$ & $1.86(0.10)^{\mathrm{w}}$ \\
\hline GSTs double nulls & 5 & 5,000 & 38 & 1 & 2 & 0 & 46 & 41 & $0.92(0.27)^{\mathrm{q}}$ & $0.82(0.22)^{\mathrm{t}}$ & $1.96(0.09)^{\mathrm{w}}$ \\
\hline
\end{tabular}

Superscript letters indicate each comparison $(\mathrm{a}-\mathrm{w})$ performed between groups

${ }^{\mathrm{a}} P=0.509 ;{ }^{\mathrm{b}} P=0.394 ;{ }^{\mathrm{c}} P=0.691 ;{ }^{\mathrm{d}} P=0.686 ;{ }^{\mathrm{e}, \mathrm{l}} P=0.225 ; \quad{ }^{\mathrm{f}, \mathrm{i}} P=0.593 ;{ }^{\mathrm{g}} P=0.786 ;{ }^{\mathrm{h}} P=0.343 ; \quad{ }^{\mathrm{m}, \mathrm{q}, \mathrm{t}} P=0.500 ; \quad{ }^{\mathrm{n}} P=0.285$, ${ }^{\mathrm{o}} P=0.462 ;{ }^{\mathrm{p}} P=0.499 ;{ }^{\mathrm{r}, \mathrm{u}} P=0.600 ;{ }^{\mathrm{s}} P=0.553 ;{ }^{\mathrm{v}} P=0.173 ;{ }^{\mathrm{w}} P=0.498$

NSCs Number of scored metaphases; BNCs Bi-nucleated cells; MNs Micronuclei; CMNs Cells with micronuclei; SE Standard error; CBPI $($ Cytokinesis-block proliferation index $)=\left[1 \times N_{1}\right]+\left[2 \times N_{2}\right]+\left[3 \times\left(N_{3}+N_{4}\right)\right] / N$, where $N_{1}-N_{4}$ represent the number of cells with $1-4$ nuclei, respectively, and $N$ is the total number of cells scored

in the causation of cancer is due to the enhancement of the effects of tobacco carcinogens by ethanol [11]. While several previous studies have addressed this topic, this is the first study about non-smoker alcoholics.

We found a significantly high frequency of SCEs among alcoholics compared to healthy controls (Table 2). Moreover, the alcohol assumption appeared to influence the lymphocyte replication capacity, as shown by RI values significantly different between alcoholics and controls $(P=0.001)$. These results are concordant with a previously published study of [Butler et al. [7]] who observed an increase of SCEs frequency in alcoholics, that was not related to age, sex, cigarette smoking and duration in years of alcohol abuse. Similarly, [29] and [24] reported an increase in SCEs rates among alcoholics, although in those studies the higher SCEs frequency was associated to smoking habit and age. Considering that SCEs seem to reflect the repair efficiency of DNA lesions by homologous recombination, these results provide further support to the hypothesis that high alcohol consumption could be associated with impaired DNA repair mechanisms, as also suggested by other authors [16, 52].

Accordingly to other published studies [6, 10], among alcoholics we also found a significantly higher frequency of CAs compared to controls (Table 3). This finding could suggest a possible clastogenic effect of ethanol in chronic alcoholics and a higher risk of cancer incidence among them. Indeed, it is known that cancer incidence among healthy individuals of a population increases with increased levels of CAs in their circulating lymphocytes [4, 5].

Although a possible aneugenic effect of ethanol has been evidenced by different authors [8, 19, 32, 49], in our study the MNs test did not reveal any significant difference between alcoholics and controls in terms of MNs frequency formation, as well as the number of cells with MNs and CBPI value (Table 4). Nevertheless, results reported in the above studies are referred to subjects that were both alcoholics and smokers, and thus the effects of smoking as a confounder factor should be taken into account. Vice versa, our selected sample included only non-smoking alcoholics, and thus the observed cytogenetic damage appeared to be exclusively due to the effects of alcohol consumption.

Overall, our data suggest that alcoholism may cause chromosome damage in humans, in terms of increased levels of SCEs and CAs. However, it cannot be concluded that the direct action of ethanol on chromosomes is responsible for these effects. Indeed, ethanol is quickly metabolized and significant levels of ROS and acetaldehyde accumulate in the blood during ethanol oxidation

\begin{tabular}{|c|c|c|c|}
\hline Journal : Large 11033 & Dispatch & $13-9-2014$ & Pages: 7 \\
\hline $\begin{array}{l}\text { Article No. : } \mathbf{3 7 3 9} \\
\text { MS Code : } \quad \text { MOLE-6782 }\end{array}$ & $\begin{array}{l}{ }^{\mathrm{LE}} \\
\boldsymbol{V}_{\mathrm{CP}}\end{array}$ & & $\begin{array}{l}\square \text { TYPESET } \\
\boldsymbol{\sim} \text { DISK }\end{array}$ \\
\hline
\end{tabular}


Table 5 Multiple regression analysis of confounding factors on SCEs and CAs frequencies in peripheral lymphocytes of the study groups

\begin{tabular}{|c|c|c|c|c|c|c|c|c|c|}
\hline \multirow[t]{2}{*}{$\mathrm{CF}$} & \multicolumn{3}{|c|}{ SCEs frequency } & \multicolumn{3}{|c|}{ CAs frequency } & \multicolumn{3}{|c|}{ MNs frequency } \\
\hline & $\beta$-co & $P$ value & $95 \%$ CI Lower-upper & $\beta$-co & $P$ value & $95 \%$ CI Lower-upper & $\beta$-co & $P$ value & $95 \%$ CI Lower-upper \\
\hline \multicolumn{10}{|c|}{ Alcoholics } \\
\hline Age & 0.33 & 0.15 & $-0.94-5.70$ & 0.21 & 0.40 & $-0.11-0.26$ & 0.21 & 0.45 & $-0.39-0.82$ \\
\hline YA & 0.60 & 0.02 & $4.16-30.99$ & 0.53 & 0.05 & $0.020-1.52$ & 0.24 & 0.40 & $-1.46-3.44$ \\
\hline \multicolumn{10}{|c|}{ Controls } \\
\hline Age & 0.37 & 0.18 & $-1.01-4.87$ & -0.05 & 0.87 & $-0.040-0.03$ & 0.23 & 0.40 & $-0.35-0.83$ \\
\hline
\end{tabular}

CF Confounding factor; $\beta$-co $\beta$-coefficient; YA Years of alcohol abuse

[35]. This last compound cause many toxic effects associated with ethanol excess and may be responsible for its mutagenic activity [6].

Ethanol metabolizing process requires different types of enzymes, including GST enzymes, able to detoxify harmful ethanol metabolites in the liver by conjugating acetaldehyde and ROS to reduced glutathione [31]. Some GST alleles, such as GSTM1 null allele, were found associated with liver diseases in alcoholics [34, 46]. However, among heavy and chronic ethanol consumers, no data are present in literature about a possible direct association between GST alleles and genomic damage measured in terms of SCEs, CAs and MNs. We investigated this possible association and observed in both groups, no statistically significant association between GST genes polymorphisms and the frequencies of SCEs, CAs, and MNs (Tables 2, 3, 4). However, the reduced sample size here considered requires further investigations with a larger number of subjects to provide convincing evidences for the absence of such correlation.

Finally, the increased levels of SCEs and CAs recorded among alcoholics appear to be associated with the duration of alcohol abuse, but not with the age of the subjects (Table 5). An age related increase of spontaneous chromosome instability was showed [2, 3, 13]. The lack of a similar age-related pattern among alcoholics could be probably due to an increased incidence of the chromosomal damage induced by alcohol among younger individuals. In this scenario the effect of alcohol abuse could obscure this relationship among alcoholics.

Acknowledgments This work was supported by Grants from the Italian Ministry of University and Scientific Research. We are grateful to Natascha Rogge for her valuable help and criticism and to all volunteers who participated in this study.

\section{References}

1. Adler RA (1992) Clinical review 33: clinically important effects of alcohol on endocrine function. J Clin Endocrinol Metab 74:957-960
2. Barnett YA, King CM (1995) An investigation of antioxidants status, DNA repair capacity and mutation as a function of age in humans. Mutat Res 338:115-128

3. Bolognesi C, Abbondandolo A, Barale R et al (1997) Age-related increase of baseline frequencies of sister chromatid exchanges, chromosome aberrations, and micronuclei in human lymphocytes. Cancer Epidemiol Biomark Prev 6(4):249-256

4. Bonassi S, Hagmar L, Strömberg U et al (2000) Chromosomal aberrations in lymphocytes predict human cancer independently of exposure to carcinogens. Cancer Res 60:1619-1625

5. Bonassi S, Znaor A, Norppa H, Hagmar L (2004) Chromosomal aberrations and risk of cancer in humans: an epidemiologic perspective. Cytogenet Genome Res 104:376-382

6. Burim RV, Canalle R, Takahashi CS et al (2004) Clastogenic effect of ethanol in chronic and abstinent alcoholics. Mutat Res 560(2): 187-198

7. Butler MG, Sanger WG, Veonett GE (1981) Increased frequency of sister-chromatid exchanges in alcoholics. Mutat Res 85(2):71-76

8. Castelli E, Hrelia P, Maffei F, Fimognari C, Foschi FG, Caputo F, Cantelli-Forti G, Stefanini GF, Gasbarrini G (1999) Indicators of genetic damage in alcoholics: reversibility after alcohol abstinence. Hepatogastroenterology 46(27):1664-1668

9. Crebelli R, Conti G, Conti L, Carere A (1989) A comparative study on ethanol and acetaldehyde as inducers of chromosome malsegregation in Aspergillus nidulans. Mutat Res 215:187-195

10. Demirhan O, Tastemir D (2008) Cytogenetic effects of ethanol on chronic alcohol users. Alcohol Alcohol 43(2):127-136

11. Du X, Squier CA, Kremer MJ, Wertz PW (2000) Penetration of $\mathrm{N}$-nitrosonornicotine $(\mathrm{NNN})$ across oral mucosa in the presence of ethanol and nicotine. J Oral Pathol Med 29:80-85

12. Elhajouji A, Cunha M, Kirsch-Volders M (1998) Spindle poisons can induce polyploidy by mitotic slippage and micronucleate mononucleates in the cytokinesis-block assay. Mutagenesis 13:193-198

13. Fenech M (1998) Important variables that influence base-line micronucleus frequency in cytokinesis-blocked lymphocytes as biomarker for DNA damage in human populations. Mutat Res 404:155-165

14. Fenech M (2000) The in vitro micronucleus technique. Mutat Res 455:81-95

15. Fenech M, Chang WP, Kirsch-Volders M, Holland N, Bonassi S, Zeiger E (2003) Human Micron Nucleus project (HUMN project): detailed description of the scoring criteria for the cytokinesis-block micronucleus assay using isolated human lymphocyte cultures. Mutat Res 534(1-2):65-75

16. Garcia-Sagredo JM (2008) Fifty years of cytogenetics: a parallel view of the evolution of cytogenetics and genotoxicology. Biochim Biophys Acta 1779(6-7):363-375

17. Gattás GJ, Saldanha PH (1997) Chromosomal aberrations in peripheral lymphocytes of abstinent alcoholics. Alcohol Clin Exp Res 21:238-243

\begin{tabular}{lll} 
Journal : Large 11033 & Dispatch : 13-9-2014 & Pages : 7 \\
Article No. : $\mathbf{3 7 3 9}$ & $\square$ LE & $\square$ TYPESET \\
MS Code : MOLE-6782 & $\boldsymbol{\sim}_{\mathrm{CP}}$ & $\boldsymbol{\sim}$ DISK \\
\hline
\end{tabular}


18. Hagmar L, Bonassi S, Stromberg U, Brogger A, Knudsen LE, Norppa H, Reuterwall C (1998) Chromosomal aberrations in lymphocytes predict human cancer: a report from the European study group on cytogenetic biomarkers and health $(\mathrm{ESCH})$. Cancer Res 58:4117-4121

19. Iarmarcovai G, Bonassi S, Sari-Minodier I, Baciuchka-Palmaro M, Botta A, Orsìere T (2007) Exposure to genotoxic agents, host factors, and lifestyle influence the number of centromeric signals in micronuclei: a pooled re-analysis. Mutat Res 615:18-27

20. IARC (1988) Alcohol drinking. international agency for research on cancer. Monographs on the evaluation of carcinogenic risk to human, vol 54. International Agency for Research on Cancer, Lyon, pp 251-321

21. IARC (2010) Alcohol consumption and Ethyl Carbamate. Monographs on the evaluation of carcinogenic risk to human, vol 96. International Agency for Research on Cancer, Lyon, pp 173-1001

22. Inoue M, Tajima K, Hirose K, Kuroishi T, Gao CM, Kitoh T (1994) Life-style and subsite of gastric cancer-joint effect of smoking and drinking habits. Int J Cancer 56:494-499

23. Kafer E (1984) Disruptive effects of ethyl alcohol on mitotic chromosomes segregation in diploid and haploid strains of Aspergillus nidulans. Mutat Res 135:53-75

24. Karaoğuz MY, Coşar B, Arikan Z, Başaran F, Menevşse A, Menevşe S (2005) Increased frequency of sister chromatid exchanges in peripheral lymphocytes of alcoholics and cigarette smokers. Cell Biol Int 29(2):165-168

25. Kaufman MH (1983) Ethanol-induced chromosomal abnormalities at conception. Nature 302:258-260

26. Kaufman MH (1985) An hypothesis regarding the origin of aneuploidy in man: indirect evidence from an experimental model. J Med Genet 22:171-178

27. Kaufman MH (1997) The teratogenic effects of alcohol following exposure during pregnancy, and its influence on the chromosome constitution of the pre-ovulatory egg. Alcohol Alcohol 32:113-128

28. Kaufman MH, Bain IM (1984) Influence of ethanol on chromosome segregation during the first and second meiotic divisions in the mouse egg. J Exp Zool 230:315-320

29. Lazutka JR, Dedonyte V, Lekevicius RK (1992) Sister chromatid exchanges in lymphocytes of normal and alcoholic subjects. Experientia 48(5):508-512

30. Lee KW, Kuo WR, Tsai SM et al (2005) Different impact from betel quid, alcohol and cigarette: risk factors for pharyngeal and laryngeal cancer. Int J Cancer 117:831-836

31. Lieber CS (1994) Alcohol and the liver: update. Gastroenterology 106:1085-1105

32. Maffei F, Fimognari C, Castelli E, Stefanini GF, Forti GC, Hrelia P (2000) Increased cytogenetic damage detected by FISH analysis on micronuclei in peripheral lymphocytes from alcoholics. Mutagenesis 15(6):517-523

33. Mandayam S, Jamal MM, Morgan TR (2004) Epidemiology of alcoholic liver disease. Semin Liver Dis 24:217-232

34. Marcos M, Pastor I, Chamorro AJ, Ciria-Abad S, GonzalezSarmiento R, Laso FJ (2011) Meta-analysis: glutathione-Stransferase allelic variants are associated with alcoholic liver disease. Aliment Pharmacol Ther 34:1159-1172

35. Nakamura K, Iwalashi K, Itoh M, Ameno K, Ijiri I, Takeuchi Y, Suwaki H (2000) Immunohistochemical study on acetaldehyde adducts in alcohol-fed mice. Alcohol Clin Exp Res 24(4):93S$96 \mathrm{~S}$

36. Nebert DW, McKinnon RA, Puga A (1996) Human drug metabolising enzyme polymorphisms effects on risk of toxicity and cancer DNA. Cell Biol 15:273-280
37. Nersesyan A, Muradyan R, Kundi M, Knasmueller S (2011) Impact of smoking on the frequencies of micronuclei and other nuclear abnormalities in exfoliated oral cells: a comparative study with different cigarette types. Mutagenesis 26(2):295-301

38. Obe G, Anderson D (1987) International commission for protection against environmental mutagens and carcinogens. ICPEMC Working Paper No. 15/1. Genetic effects of ethanol. Mutat Res 186(3):177-200

39. Parry EM, Parry JM, Corso C et al (2002) Detection and characterization of mechanisms of action of aneugenic chemicals. Mutagenesis 17(6):509-521

40. Pemble S, Schroeder KR, Spencer SR, Meyer DJ, Hallier E, Bolt HM, Ketterer B, Taylor JB (1994) Human glutathione S-transferase theta (GSTT1): cDNA cloning and the characterization of a genetic polymorphism. Biochem J 300:271-276

41. Rey M, Palermo AM, Muñoz ER (1992) Nondisjunction induced by ethanol in Drosophila melanogaster females. Mutat Res 268(1):95-104

42. Roy B, Majumder PP, Dey B, Chakraborty M, Banerjee S, Roy M, Mukherjee N, Sil SK (2001) Ethnic differences in distributions of GSTM1 and GSTT1 homozygous "Null" genotypes in India. Hum Biol 73(3):443-450

43. Santovito S, Cervella P, DelPero M (2011) In vitro aneugenic effects of the fungicide thiabendazole evaluated in human lymphocytes by the micronucleus assay. Arch Toxicol 85:689-693

44. Santovito A, Schilirò T, Castellano S, Cervella P, Bigatti MP, Gilli G, Bono R, DelPero M (2011) Combined analysis of chromosomal aberrations and glutathione S-transferase M1 and T1 polymorphisms in pathologists occupationally exposed to formaldehyde. Arch Toxicol 85:1295-1302

45. Santovito S, Cervella P, DelPero M (2014) Increased frequency of chromosomal aberrations and sister chromatid exchanges in peripheral lymphocytes of radiology technicians chronically exposed to low levels of ionizing radiations. Environ Toxicol Phar 37:396-403

46. Savolainen VT, Pajarinen J, Perola M, Penttila A, Karhunen PJ (1996) Glutathione-S-Transferase GST M1 "Null" genotype and the risk of alcoholic liver disease. Alcohol Clin Exp Res 20(8):1340-1345

47. Seitz HK, Stickel F (2006) Risk factors and mechanisms of hepatocarcinogenesis with special emphasis on alcohol and oxidative stress. Biol Chem 387(4):349-360

48. Sierra-Torres MS, Arboleda-Moreno YY, Hoyos LS, SierraTorres CH (2004) Chromosome aberrations among cigarette smokers in Colombia. Mutat Res 562(1-2):67-75

49. Stich HF, Rosin MP (1983) Quantitating the synergistic effect of smoking and alcohol consumption with the micronucleus test on human buccal mucosa cells. Int J Cancer 31(3):305-308

50. Vioque J, Barber X, Bolumar F, Porta M, Santibáñez M, de la Hera MG, Moreno-Osset E, PANESOES Study Group (2008) Oesophageal cancer risk by type of alcohol drinking and smoking: a case-control study in Spain. BMC Cancer 8(1):221

51. Walsh P, Metzger DA, Higuchi R (1991) Chelex 100 as a Medium for simple extraction of DNA for PCR-based typing from forensic material. Biotechniques 10:506

52. Wilson DM 3rd, Thompson LH (2007) Molecular mechanisms of sister-chromatid exchange. Mutat Res 616(1-2):11-23

53. Zhong S, Wyllie AH, Barnes D, Wolf CR, Spurr NK (1993) Relationship between GSTM1 genetic polymorphism and susceptibility to bladder, breast and colon cancer. Carcinogenesis 14:1821-1824 